\title{
Önkormányzati rendészeti modellek ${ }^{1}$
}

\section{BACSÁRDI József ${ }^{2}$}

\begin{abstract}
Az egyes külföldi önkormányzati rendészeti megoldások összehasonlító elemzésével öt nagyobb önkormányzati rendészeti modellt lehet megkülönböztetni. Az egyes önkormányzati rendészeti modelleket egy-egy kiválasztott külföldi állam (Finnország, Szlovénia, Franciaország, Ausztria) önkormányzati rendészetének vázlatos ismertetésével mutatunk be, kiemelve az egyes modellek hazai önkormányzati rendészethez képest meghatározó föbb vonásait.
\end{abstract}

Kulcsszavak: önkormányzati rendészet, magánbiztonság, rendészet

\section{Bevezetés}

Az önkormányzati rendészet azon rendészeti jogágak egyike, amelynek tudományos igényú hazai kutatása a közelmúltban éppen csak megkezdődött. ${ }^{3}$ A megkezdett kutatások alapvetően két nagyobb területet fognak át:

- a hazai önkormányzati rendészet átfogó dogmatikai, múködési és percepciós vizsgálatát, valamint

- a külföldi önkormányzati rendészeti gyakorlatok és önkormányzati rendészeti szervek tanulmányozását.

Meglátásom szerint a hazai önkormányzati rendészet kutatása során nem mellőzhető a külföldi önkormányzati rendészeti példák feldolgozása, mivel attól nem választható szét. ${ }^{4}$

A külföldi önkormányzati rendészet tanulmányozásának jelentősége az alábbiakban foglalható össze:

1. A külföldi önkormányzati rendészeti megoldások vizsgálatával összehasonlíthatóvá válnak az önkormányzati rendészet jogintézményei, amellyel az egyes államok és hazánk önkormányzati rendészetének elhelyezése egy nagyobb kontextusban lehetségessé válik.

\footnotetext{
A mű a KÖFOP-2.1.2-VEKOP-15-2016-00001 azonosítószámú, „A jó kormányzást megalapozó közszolgálat-fejlesztés" elnevezésű kiemelt projekt keretében múködtetett Ludovika Kutatócsoport keretében, a Nemzeti Közszolgálati Egyetem felkérésére készült.

2 BACSÁRDI József dr., PhD-hallgató (PPKE JÁK), Bábolnai Közös Önkormányzati Hivatal, aljegyző József BACSÁRDI PhD student, Joint Local Governmental Office of Bábolna, deputy town clerk orcid.org/0000-0001-5375-3936, jozsef.bacsardi@gmail.com

3 Bacsárdi-Christián (2017) 27-38.

4 Lásd például: Bacsárdi (2017) 123-128.
} 
2. Az összehasonlítással jobban felismerhetővé válnak az anomáliák, így megállapíthatók, hogy melyek azok a lényeges pontok, hibák a hazai önkormányzati rendészet területén, amelyeken javítani szükséges a hatékonyság növeléséhez.

3. Megismerhetővé válnak a legjobb gyakorlatok (best practices). A legjobb gyakorlatok segíthetnek abban, hogy a megismert anomáliákra máshol kipróbált megoldási javaslatok szülessenek, természetesen megfelelő adaptációval.

4. A hatékony, határon átnyúló, nemzetközi együttmúködés alapja az, hogy megismerjük más országok gyakorlatát, jogintézményeit. Amennyiben meg tudjuk ismerni egymás tevékenységét, akkor az segíthet abban, hogy müködő kooperációt alakítsunk ki.

5. Az összehasonlítással szélesedik a kutatók, illetve a döntéshozók látószöge.

A rövid, mindössze öt pontot felsoroló példákból jól kitűnik, hogy a külföldi önkormányzati rendészet tanulmányozása és megértése nélkül egyszerűen féloldalas és hiányos lesz az önkormányzati rendészeti tudásunk.

\section{Mi az az önkormányzati rendészet?}

Az önkormányzati rendészet fogalmának meghatározása kulcsfontosságú akkor, amikor egy szerző önkormányzati rendészeti tárgyú dolgozatot kíván közreadni. Nem bocsátkozva hosszas fejtegetésekbe, leszögezném, hogy az önkormányzati rendészetnek alapvetően két jelentése van:

1. az önkormányzatok rendészeti irányú tevékenysége,

2. szervezet.

Az önkormányzati rendészet központi figurája értelemszerűen az önkormányzat. Azon diktatúrákban, ahol nem létezik a helyi közösségek autonómiájaként megnyilvánuló helyi önkormányzati rendszer, csak valamilyen települési rendészetről beszélhetünk. ${ }^{5}$

Az önkormányzati rendészet mint tevékenység nagyon széles spektrumú feladatellátást foglalhat magában, kezdve az önkormányzatok rendészeti tárgyú (jog)szabályalkotásától a központi jogszabályok rendészeti jellegű feladatainak végrehajtásán keresztül az önkormányzatok más rendészeti szereplőkkel való együttmúködésével bezárólag.

Az önkormányzati rendészet mint szervezet ezzel szemben az önkormányzat által irányított és fenntartott szervezet, amely felhatalmazással rendelkezik kényszer alkalmazására, és feladata az önkormányzat rendészeti tevékenységeinek, vagy - ha úgy tetszik - politikájának megvalósítása, végrehajtása. Önkormányzati rendészeti szerv lehet - egy adott állam jogszabályaitól függően - az önkormányzati rendőrség is.

Lásd például hazánkban a tanácsrendszert. A tanácsok alkalmazhattak közterület-felügyelőket, illetve mezőőröket sajátos rendészeti jellegű feladataik ellátása érdekében. 
Meglátásom szerint egy önkormányzat rendészeti téren csak akkor lehet igazából hatékonyan cselekvő alany, amennyiben ilyen feladatot ellátó szervezettel rendelkezik, ezért dolgozatomban az önkormányzati rendészet alatt elsősorban az önkormányzati rendészeti szervezetrendszert fogom érteni.

\section{Az önkormányzati rendészet korszakai}

Amikor egy külföldi állam önkormányzati rendészetét vesszük górcső alá, akkor nem mellőzhető az adott állam rendészeti és amennyiben van neki, önkormányzati rendészeti történelmének áttekintése, ugyanis a történeti előzmények ismerete szükséges a jelenbeli állapotok, tendenciák megértéséhez.

Ahogy azt a dolgozatom későbbi részében látni fogjuk, az önkormányzati rendészet sarokpontja az, hogy mekkora teret enged a központi hatalom az önkormányzatok rendészeti jellegű tevékenységének.

A középkori európai államok történetének egyik jellegzetessége, hogy a királyi, illetve központi hatalom megerősítésének szándéka az államon belülről és azon kívülről jövő kihívásokkal szemben. Ezen kihívások az államokban természetszerǔen érintették a helyi közbiztonság kialakításáért felelős szervezetek tevékenységét.

A középkori államok formálódásakor a helyi rendvédelem alapvetően a helyi közösségeken, a földesurak hatalmán alapult. ${ }^{6}$ A korai keresztény királyságokban az államhatalom egyszerűen nem lehetett elég erős ahhoz, eszközei pedig egyszerűen hiányoztak ahhoz, hogy folyamatosan és érdemben befolyásolja a helyi közbiztonságot. Ez a helyi, értve itt ezalatt az állami szervektől való független, autonóm, rendészet korszaka.

A központi hatalom erősödésével a központi hatalmat gyakorlók azzal az alapvető kérdéssel találták magukat szembe, hogy eszközeikkel milyen mértékben érdemes befolyásolniuk a helyi közbiztonságot. Ezen kérdésre Anglia és Franciaország ellentétes választ adott, amely válaszok mai napig kihatnak az angolszász vagy francia rendészeti modellhez tartozó államok helyi rendészetére is.

Anglia az alulról szerveződő rendőrség modelljét tette magáévá, amely azt jelenti, hogy a helyi rend fenntartása alapvetően a helyi közösségek irányítási jogán nyugodott. ${ }^{7}$

Angliától eltérő utat választott Franciaország, ahol a központosítási törekvések nyomán stabil, hosszú időn keresztül fennmaradt abszolutizmus fejlődött ki. Az abszolutizmus kifejlődésével párhuzamosan pedig a központosítási törekvések elvezettek addig, hogy az állami szervek, értve ezalatt a csendőrséget és elődszervezeteit, illetve a fokozatosan állami irányítás alá helyezett városi rendőrségeket, egyre komolyabb szerepet kezdtek el játszani a helyi rendvédelem területén. ${ }^{8} \mathrm{Az}$ állami térnyerés mellett azonban még Franciaországban is sokáig megmaradt a lehetőség a helyi közösségek számára a helyi rendészeti politikájuk általuk irányított szervezeteken keresztül törté-

\footnotetext{
Christián (2011) 31.

Christián (2011) 35-36. Rendkívül érdekes, hogy az Angliában is kétség kívül meglévő központosítási törekvések ellenére a helyi közösségek közbiztonságban játszott szerepe megmaradhatott.

8 Bacsárdi (2018) 264-265.
} 
nő megvalósítására. Nyugodtan kijelenthetjük azonban, hogy a felülről építkező rendészeti modell a helyi rendvédelemben betöltött domináns állami szerepen nyugszik. A két klasszikus rendészeti modell egyes elemeit, mint például a csendőrség intézményét, széles körben vették át az európai államok, amikor saját rendészetük fejlesztéséről, átalakításáról döntöttek.

A 19. század gyors gazdasági fejlődése mindkét rendészeti modellt hasonló kihívások elé állította, ugyanis egyre nagyobb igény merült fel a professzionális rendőri, rendészeti tevékenység iránt. Teret nyert az államok rendészetében a minden területen bevethető rendőr képe. ${ }^{9}$ Ez alapvetően a felülről építkező rendészeti modellben járt azzal, hogy az önkormányzati rendészet szerepe csökkent az állami rendészet rovására, ${ }^{10}$ és tudomásunk van arról, például Kanada esetében, hogy egy alulról építkező rendészeti modellt használó államban is az állami rendészet vált dominánssá az önkormányzati rendészettel szemben. Ezt az időszakot az önkormányzati rendészet hanyatló korszakaként jellemezhetjük.

A 20. század második felére azonban ez a minden területen „bevethető rendőr” képe lassan eltűnt, ugyanis a látható járőrszolgálat biztosítása, bűnmegelőzés és a bűnüldözés feladatai növekvő nehézséget okoztak és okoznak a rendőrség számára. ${ }^{11} \mathrm{Meg}$ jelent a specializáció igénye, ugyanis a motorizációval, népességrobbanással, urbanizációval együtt olyan helyi rendészeti jellegű igények jelentek meg, amelyek teljesítésére a helyi önkormányzatok alkalmasabbnak tưntek és tűnnek, mint az állam. Az önkormányzati rendészet immár növekvő jelentőségének lehetünk tanúi például Franciaországban, Spanyolországban, Szlovákiában, Lengyelországban és hazánkban is, valamint még a mereven felülről építkező rendészeti modellt alkalmazó államokban, mint Dánia és Finnország is, igyekeznek a rendészetet a helyi közösséghez közelebb hozni a community policing keretében. Az önkormányzati rendészet ezen, harmadik korszaka mind a mai napig tart és a rendészettudomány művelői számára mindenképpen komoly érdeklődésre tart számot, hogy mi lesz a folyamat következő állomása vagy végeredménye.

\section{Önkormányzati rendészeti modellalkotás}

Amennyiben elkezdjük vizsgálni a külföldi önkormányzati rendészeti tapasztalatokat, óhatatlanul is megállapíthatjuk, hogy az egyes államok önkormányzati rendészetének vannak olyan vonásai, amelyek megegyeznek, így ezen államokat érdemes egy kategóriába sorolni.

Közismert Bill Tupman és Alison Tupman rendészeti modellje, ${ }^{12}$ amely három nagy kategóriába sorolja az államok rendészetét:

\footnotetext{
Donelly (2013) 4.

Lásd például: Bacsárdi (2018) 266.

Donelly (2013) 4.

Tupman-Tupman (1998) 12-13.
} 
1. nemzeti vagy centralizált modell, amelyben kizárólag egy állami rendőrség működik,

2. napóleoni modell, amelyben az állami rendészet rendőrségre és csendőrségre oszlik,

3. decentralizált modell, amely nagy változatosságot mutat, azonban megállapítható, hogy több önálló, decentralizált rendőrség múködik az ezen modellt alkalmazó államokban.

Tupmanék modellje hasonlatos az angolszász és francia rendészeti modell felosztásához és nagyon hasznosnak tekinthetjük, amennyiben egy állam mint egész tekintetében vizsgáljuk a rendészetet, azonban az önkormányzati rendészet szemszögéből elnagyolt és kevés támpontot nyújt, nem igazán alkalmas pontos kategorizálásra, ugyanis önkormányzati rendészet a Tupman-modell mindhárom kategóriájában létezhet.

A Tupman-modell eredményeit felhasználva, az önkormányzati rendészetre vonatkozó modellek megalkotását érdemes az állam és az önkormányzat közötti hatáskörmegosztásból vizsgálni. Az ilyen irányú vizsgálatot követően egy skálát lehet felrajzolni, a gyakorlatilag nem létező önkormányzati rendészettel rendelkező országoktól azon országokkal bezárólag, ahol domináns, mondhatni egyeduralkodó aktor az önkormányzati rendészet. Ezek alapján az alábbi kategóriák alakíthatók ki:

1. Szigorúan államközpontú modell, amelyben nincs vagy csak marginális az önkormányzati rendészet szerepe.

2. Megengedő államközpontú modell, amelyben kizárólag állami rendőrség létezik, azonban az önkormányzatok létrehozhatnak korlátozott hatáskörú önkormányzati rendészeti szerveket, rendészeti feladataik ellátására.

3. Államközpontú vegyes modell, amelyben az önkormányzatok számára lehetőség önkormányzati rendőrség létrehozása, így a rendőrség decentralizációja megvalósul, azonban ezen önkormányzati rendőrségek csak kiegészítő szereppel bírnak a domináns állami rendőrség - és esetenként csendőrség - mellett.

4. Vegyes modell, amelyben az önkormányzatok által létrehozott rendőrség elláthatja az állami rendőrség feladatait, így szinte teljes mértékben helyettesítheti az önkormányzati rendőrség az állami rendőrséget.

5. Önkormányzati modell, ahol nem létezik települési szinten állami, kizárólag önkormányzati rendőrség.

A továbbiakban az egyes modelleket, az önkormányzati modell kivételével, ugyanis önkormányzati modellt alkalmazó államot nem ismerünk, egy-egy állam önkormányzati rendészetének vázlatán keresztül mutatom be.

\section{Szigorúan államközpontú modell}

A szigorúan államközpontú modellben nem vagy csak marginálisan létezik az önkormányzati rendészet. A szigorúan államközpontú modellt alkalmazó államok rendésze- 
tileg tipikusan centralizált államok, a települések rendészeti igazgatása az állam irányítása alatt van egy egységes állami rendőrség képében.

Ezen modellhez tartoznak az északi államok (például Dánia, Svédország, Finnország) és tipikusan a törpeállamok. Az olyan törpeállamok, mint például Málta tekintetében a centralizáció érthető, ugyanis az állam méreténél fogva nem feltétlenül szükséges a rendészet, illetve a rendőrség decentralizációja. ${ }^{13} \mathrm{Az}$ északi államok centralizált rendészeti struktúrájának kialakulásának vázlatára jelen tanulmány nem vállalkozhat, azonban megjegyzendő, hogy a rendészet centralizációja mindenképpen érdeklődésre tart számot, ugyanis az északi államokban hagyományosan nagy az önállósága az önkormányzatoknak, a közigazgatás sok tekintetben decentralizáltabban múködik, mint hazánkban.

A szigorúan államközpontú modellt alkalmazó államok közül kiemelésre érdemes Finnország rendészete. A szigorúan államközpontú modell alkalmazása ugyanis Finnországban nem jár azzal, hogy a rendőrség elszakad a helyi közösségektől, hanem a rendőrség, immár több évtizede, törekszik arra, hogy minél közvetlenebb kapcsolatokat építsen ki a helyi közösségekkel, tudatosan alkalmazva a community policing elveit $^{14}$ és építve az átláthatóság előnyeire. ${ }^{15}$

A finn önkormányzatok az állami rendőrséggel több területen szorosan együttmúködnek, problémák esetén folyamatosan egyeztetnek (például gyermekvédelem területén felmerülő problémák), azonban az önkormányzatoknak nincs formális ráhatásuk a rendőrség múködésére. Míg hazánkra jellemző, hogy az önkormányzatok akár pénzügyi eszközökkel is támogatják a rendőrség múködését, ilyen támogatásokra Finnországban nemigen találhatunk példát. A finn önkormányzatok a rendőrség mellett még a magánbiztonsági szolgáltatásokra támaszkodhatnak, amennyiben olyan feladat merül fel (például objektum őrzése), amely indokolja az ilyen szolgáltatások igénybevételét. Megemlítendő még az önkéntesek szerepe, akik az önkormányzati rendezvények lebonyolítása során egyes rendészeti jellegú feladatok (például közterületi parkolás biztosítása) ellátásában érdemi hatáskör nélkül segédkeznek. ${ }^{16}$

A szigorúan államközpontú modellben az önkormányzatok a települési közbiztonsággal kapcsolatos problémáik esetén az állami rendőrségre kénytelenek támaszkodni, míg az állami rendőrségnek fokozottan kell ügyelnie arra, hogy feladatai ellátása esetén ne távolodjon el a helyi közösségektől. A szigorúan államközpontú modellben tehát a rendőrség és az önkormányzatok közötti folyamatos kooperáció biztosítása az egyik legfontosabb sarokkő a települések közbiztonságának megteremtése érdekében.

\footnotetext{
13 Málta esetében megjegyzendő, hogy létezik a Local Wardens intézménye, amely intézmény munkavállalói tipikusan helyi rendészeti feladatokat látnak el, azonban ezen szolgálatok, bár együttmüködnek az önkormányzatokkal, magánvállalkozások. Lásd: Private Guards and Local Gardens Act (Málta).

14 Donelly (2013) 67-68.

Christián (2016) 699.

16 A finnországi helyi rendészet vázlata Markku Leppälahti, Ypäjä Község Önkormányzatának önkormányzati tanácsának tagjával készített interjún alapul.
} 


\section{Megengedő államközpontú modell}

A megengedő államközpontú modellhez tartozó államokban, hasonlóan a szigorúan államközpontú modellt alkalmazó államokhoz, egy központi, állami rendőrség létezik, azaz a rendőrség centralizált, az önkormányzatok nem hozhatnak létre önkormányzati rendőrségeket. A két modell közötti eltérés az, hogy az önkormányzatok számára az állam lehetőséget biztosít önkormányzati rendészeti szervezet létrehozására. Hangsúlyozandó, hogy a megengedő államközpontú modellben nem lehetséges önkormányzati rendőrség létrehozása, kizárólag nem rendőrségi jogállású önkormányzati rendészeti szervek alakíthatók ki.

Ezen modellhez tartozó államok önkormányzatai sokrétủ rendészeti feladatokkal rendelkeznek, azonban rendészeti feladataik megvalósításában nagy mértékben a rendőrségre támaszkodnak, saját önkormányzati rendészeti szerveik kiegészítő szerepet látnak el a közbiztonság megteremtése során.

A megengedő államközpontú modellhez olyan közép-európai államok tartoznak, mint hazánk, Szlovénia és Lengyelország. ${ }^{17} \mathrm{~A}$ továbbiakban Szlovénia önkormányzati rendészetét fogom vázlatosan ismertetni.

Szlovéniában a rendőrség a Belügyminisztérium irányítása alatt álló, centralizált, hierarchikus szervezet, amely kulcsszerepet játszik a biztonság, közrend és bünmegeloozés biztosításában. ${ }^{18} \mathrm{~A}$ rendőrségektől függetlenül a szlovén helyi önkormányzatoknak lehetőségük van arra, hogy létrehozzanak önkormányzati felügyelói szolgálatokat közbiztonsággal és közrendvédelemmel kapcsolatos helyi feladatok ellátására. Az önkormányzati felügyelői szolgálatok összehasonlítva a rendőrséggel a szlovén rendvédelemben jóval kisebb jelentőséggel bírnak, amelyet jól mutat, ha összevetjük az önkormányzati felügyelői szolgálatok és a rendőrség állományának létszámát. A 2015-ös adatok szerint a rendőrségi személyi állománya Szlovéniában 6991 fô, míg az önkormányzati felügyelői szolgálatok létszáma 169 fô. A 169 fő önkormányzati felügyelő 190 önkormányzat területén lát el szolgálatot. ${ }^{19}$ Megjegyzendő, hogy mindösszesen 20 olyan önkormányzat van Szlovéniában, ahol nem foglalkoztatnak önkormányzati felügyelőt, ${ }^{20}$ amely a nyilvánvaló alacsony felügyelôi létszám ellenére figyelemre méltó adat, ugyanis azt sejteti, hogy az önkormányzatok feladataik ellátása során támaszkodnak az önkormányzati felügyelókre.

Érdemes még áttekinteni az önkormányzati felügyelők alapvető feladatait, hiszen a feladatokon keresztül látható, hogy az önkormányzatok rendészeti feladatai milyen területeket fognak át. Az önkormányzati felügyelői szolgálatok alapvető feladatai az alábbiak: ${ }^{21}$

\footnotetext{
www.lexlege.pl/ustawa-o-strazach-gminnych/ (2018. 11. 01.).

Sotlar-Dvojmoč (2015) 331.

Sotlar-Dvojmoč (2015) 331.

Sotlar-Dvojmoč (2015) 336.

Sotlar-Dvojmoč (2015) 338.
} 
1. a lakóövezetekben történő biztonságos és egyenletes forgalom biztosítása;

2. a környezet és az utak védelme a településeken és a külterületeken;

3. önkormányzati utak, szórakozási és más övezetek biztonságának garantálása;

4. köztulajdon, természeti és kulturális örökség védelme;

5. közrend és béke fenntartása.

Az önkormányzati felügyelők a közlekedés biztonságának érdekében jogosultak ellenőrizni a közlekedési és gyalogos területeket, biztonsági övek becsatolását, a maximális és néhány gépjárműnél a minimális sebesség betartását, a megállást, a parkolást, a mozgáskorlátozottak számára kijelölt parkolóhelyen a parkolást, várakozást, illetve azokat a területeket, ahol a parkolás nem megengedett. ${ }^{22}$

Az önkormányzati felügyelők feladatait áttekintve tálcán kínálja magát a lehetőség, hogy vessük össze hazánk önkormányzati rendészeti kötelezettségeket ellátó személyeinek és a szlovén önkormányzati felügyelők feladatait, ugyanis mindkét állam ugyanabba a rendészeti modellbe tartozik. A feladatellátásra fókuszálva első látásra is szembetûnő, hogy Szlovéniában mindössze az önkormányzati felügyelő nevezhető ki önkormányzati rendészeti feladatok ellátására, addig hazánkban hat különböző típusú önkormányzati rendészeti feladatokat ellátó személyt ${ }^{23}$ is ismerünk, amely mindenképpen elgondolkodtató. A feladatellátás összevetését követően megállapíthatjuk, hogy a feladatok túlnyomórészt megfeleltethetők a hazai önkormányzati rendészeti feladatokat ellátó személyek feladatainak, ${ }^{24}$ azzal a kiegészítéssel, hogy az önkormányzati rendészeti joganyag Szlovéniában egységes, míg hazánkban széttagolt, ${ }^{25}$ illetve Szlovéniában valamivel több hatáskörrel rendelkeznek az önkormányzati felügyelők a közlekedésrendészet területén, mint a hazai az önkormányzati rendészeti feladatokat ellátó személyek.

A megengedő államközpontú modellben tehát, ahogy azt Szlovénia esetében láthattuk, az önkormányzatok nagy mértékben kénytelenek támaszkodni az állami rendőrségre mint a közbiztonság megteremtésének fő letéteményesére. Az önkormányzatok azonban alkalmazhatnak olyan személyeket, akik hatékonyan támogathatják a rendőrség munkáját, illetve érvényt szerezhetnek az őket alkalmazó önkormányzat közbiztonsággal kapcsolatos politikájának. Kiemelendő, hogy az önkormányzatok a megengedő államközpontú modellben - mivel nem hozhatnak létre saját rendőrséget, csak korlátozottabb hatáskörü önkormányzati rendészeti szervezetet - kevésbé lehetnek képesek arra, hogy a közbiztonság látványos javulása esetén az eredményeket maguknak vindikálják, magukat a közbiztonság megteremtésében kulcsszerepet játszó aktorként definiálják.

22 Sotlar-Dvojmoč (2015) 338.

23 Közterület-felügyelő, mezőőr, önkormányzati természetvédelmi őr, rendészeti feladatokat ellátó erdészeti szakszemélyzet, rendészeti feladatokat ellátó jogosult erdészeti szakszemélyzet, halászati őr.

24 Lásd: a közterület-felügyeletről szóló 1999. évi LXIII. törvény a fegyveres biztonsági ôrségről, a természetvédelmi és a mezei őrszolgálatról szóló 1997. évi CLIX. törvény, a természet védelméről szóló 1996. évi LIII. törvény, az erdőről, az erdő védelméről és az erdőgazdálkodásról szóló 2009. évi XXXVII. törvény, a halgazdálkodásról és a hal védelméről szóló 2013. évi CII. törvény.

25 Sotlar-Dvojmoč (2015) 35. 


\section{Államközpontú vegyes modell}

Az államközpontú vegyes modellhez tartozó államok a Tupman-modell szerint, ellentétben a korábban vázolt két modellel, a decentralizált (és sok esetben a napóleoni) rendőrségi modellhez tartoznak, ugyanis az önkormányzatok létrehozhatnak saját fenntartás és irányítás alatt álló rendőrséget. Az államközpontú vegyes modellt alkalmazó államokra jellemző és ez a modell egyik alapvető sajátossága, hogy az állami rendészetet nem helyettesítheti az önkormányzati rendőrség, hanem csak kiegészítő jellegú szerepet játszik. Az önkormányzati rendőrség a feladatait ebben a modellben párhuzamosan látja el az államival, azonban feladatai szigorúan a helyi közrend és közbiztonság önkormányzati fenntartásához kapcsolódnak.

Az államközpontú vegyes modellhez tartozik többek között Spanyolország, ${ }^{26}$ illetve a modell mintájaként az alábbiakban röviden bemutatott Franciaország is.

Megemlítendő, hogy Franciaország történelmére alapvetően a három pólusból álló rendészet (állami rendőrség, csendőrség, önkormányzati rendészet) volt mindig is a jellemző. A második világháború alatt és az azt követő néhány évben a három pólusú rendészet harmadik pólusa, az önkormányzati rendészet gyakorlatilag megszúnt, a helyi rendvédelem a nagyobb településeken az állami rendőrség (Police Nationale) és a kisebb településeken és a vidéki területeken a csendőrség (Gendarmerie Nationale) körül összpontosult. A két pólusú rendészeti modell azonban az utóbbi évtizedekben ismét három pólusúvá kezdett válni, az önkormányzati rendészet jelentőségének növekedésének lehetünk tanúi, tekintettel arra, hogy az állami rendvédelmi szervek nem bizonyultak elég hatékonynak az önkormányzatok érdekkörébe eső rendészeti feladatok ellátásában. ${ }^{27}$ Az önkormányzati rendészet jelentőségének növekedését jól példázza az egyes rendészeti ágakban dolgozók létszámának összevetése. A rendőrség létszáma 2013-ról 2016-ra, mindösszesen 3\%-kal (142 300 főről 145600 főre) nőtt, a csendőrség létszáma lényegében stagnált, minimálisan nőtt (95 300 főról 95900 főre), míg az önkormányzati rendészeti szervek által foglalkoztatottak létszáma 16\%-kal nőtt (27 259 fốről 31753 fốre). ${ }^{28}$

A francia önkormányzati rendészet sajátossága, hogy az önkormányzati rendészet szervezetrendszere három különböző ágra bontható, név szerint az önkormányzati rendőrségre, a mezei őrségre és a közútbiztonsági felügyelőkre. Az önkormányzati rendőrség létrehozásán túl tehát egy francia önkormányzat más önkormányzati rendészeti szervezet felállításában is gondolkodhat, azonban rendőrségi jogosítványokkal csak az önkormányzati rendőrök és a mezei őrök rendelkeznek, a közútbiztonsági felügyelők nem.

Az, hogy egy önkormányzat létrehoz-e önkormányzati rendészeti szervezetet, teljes mértékben az önkormányzat döntésétől függ, ugyanis a rendészeti szervek finanszírozása saját forrásból történik. Amennyiben önkormányzati rendészeti szerv létrehozására nem kerül sor, akkor a rendőrség és a csendőrség látja el a település rendészeti feladatait.

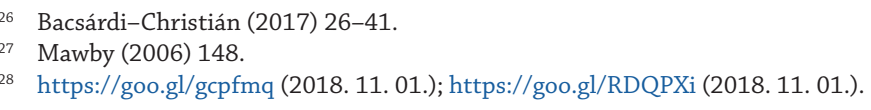


A francia önkormányzati rendészet feladatait érdemes külön vizsgálni az egyes önkormányzati rendészeti szervek vonatkozásában.

Az önkormányzati rendőrség jogszabályban meghatározott célja, hogy biztosítsa a közrendet, a védelmet, a közbiztonságot és a közegészséget, ${ }^{29}$ azonban ezen célokat az állami rendvédelmi szervekkel együttmúködve, azokat kiegészítve láthatja el, szoros prefektusi és ügyészi, azaz állami felügyelet mellett. ${ }^{30}$

A francia szabályozás példálózó felsorolást ad arra nézve, hogy melyek az önkormányzati rendőrség feladatai a közrend, a védelem, a közbiztonság és a közegészség tekintetében. A felsorolás része: ${ }^{31}$

1. a közterületek védelme,

2. köznyugalom megzavarását okozó magatartások elhárítása,

3. rend fenntartása nagyobb tömegeket vonzó rendezvényeken,

4. élelmiszerbiztonsági felügyelet gyakorlása,

5. megfelelő óvintézkedések megtétele a közveszély elhárítására,

6. ideiglenes intézkedések meghozatala mentálisan beteg személyekkel szemben, amennyiben mentális állapotuk a közerkölcsöt, személyeket vagy vagyont fenyeget,

7. veszélyes vagy vadállatok kóborlása esetén eljárás lefolytatása.

Az önkormányzati rendőrök jellemzően a települések belterületén látnak el szolgálatot, míg a külterületeken az önkormányzatok mezei őröket alkalmazhatnak. A francia mezei őrök feladata a vidéki rendészeti feladatok ellátásához való hozzájárulás. ${ }^{32} \mathrm{Az}$, hogy a jogszabály a „hozzájárulás” szót használja, jól példázza azt, hogy a külterületeken is csak kiegészítő jellegű az önkormányzati rendészet az állami rendészethez képest.

A mezei őrök hatáskörei a vidéki tulajdon védelmére, az erdészeti szabályok betartatására irányulnak. Ezek magukban foglalják például a termény - és falopásokkal, rongálásokkal, erdei utakon történő közlekedéssel, környezetvédelemmel (vad- és halvédelem, élő vizek védelme) kapcsolatos hatásköröket. ${ }^{33}$

A francia önkormányzatok közlekedésrendészeti hatásköröket is gyakorolhatnak a települések belterületén az állami utak, a megyei utak, illetve az összekötő utak, és a külterületi közutak vonatkozásában. ${ }^{34} \mathrm{Az}$ utak felügyeletét az önkormányzat nem kizárólag önkormányzati rendőrökkel, hanem egy viszonylag új jogfejlődés eredményeképpen nem rendőri besorolású közútbiztonsági felügyelőkkel is elláthatja.

A közútbiztonsági felügyelők eljárnak a szabálytalanul vagy tilos jelzés ellenére parkolókkal szemben, illetve a Code des assurances (Biztosítási kódex) ${ }^{35}$ felhatalmazza

\footnotetext{
Code général des collectivités territoriales 2212-2. cikkely.

Code de la sécurité intérieure 511-2. cikkely.

Code général des collectivités territoriales 2212-2. cikkely.

Code de la sécurité intérieure 521-1. cikkely.

Lásd: Code de procédure pénale 22. § cikkely, Code forestier 1. könyv, 6. cím, Code de lenvironnement 172-1. cikkely.

Code général des collectivités territoriales 2213. cikkely.

Code des assurances 211-21-5. cikkely.
} 
a közútbiztonsági felügyelőket a biztosítással nem rendelkező gépjárművekkel kapcsolatos eljárások lefolytatására. A felügyelők feladatkörébe tartoznak még az alábbiak:

1. közutak és közterületek tisztaságának ellenőrzése, ${ }^{36}$

2. zajszint mérése (erre lehetőség van szomszédjogi jogvitákban is a polgármester rendelkezése alapján), ${ }^{37}$

3. szállítójármúvek mozgásának, megállásának és telephelyen parkolásának ellenőrzése. ${ }^{38}$

Ahogy jelen alfejezet elején erről szóltam, az önkormányzati rendészet egyre jelentősebb szereplővé válik Franciaországban. Az önkormányzati rendészet szerepének növekedését jól jellemzi Marseille önkormányzati rendőrségének ${ }^{39}$ gyors ütemű fejlődése. Marseille 2011-ben még a legrosszabb bűnözési statisztikájával rendelkező települése volt Franciaországnak. 2011-ben azonban erőteljesen elkezdték növelni az önkormányzati rendőri állományt, így az állomány nagysága a 2011-es 180 főről 2017-re 420 főre emelkedett. Az önkormányzati rendőrök fegyveres kiképzést kaptak és lőfegyverekkel szerelték fel őket, ezzel a bírságoló, közterületek rendjét fenntartó szervezet helyett, a fegyveres szerv képe kezdett el erősödni. Az önkormányzati rendőrök létszámának és képzettségének emelése mellett az önkormányzati rendőrség technikai felszereltsége is jelentősen javult. 2011-ben még csak 10 térfigyelő kamerát működtetett az önkormányzati rendőrség, azonban 2017-ben ez a szám már közel százszorosa (!) volt a 2011-es darabszámnak. A térfigyelő kamerarendszert intelligens szoftverekkel látták el, így emberi közremúködés nélkül is képes a kamerarendszer a normálistól eltérő jelenség észlelése esetén megfelelő jelzést küldeni. Az önkormányzati rendőrség fejlesztésének hatása jól mérhető a bűnözési statisztikákkal, ugyanis Marseille bűnözési statisztikái jelenleg átlagosnak mondhatók. A statisztikai mutatószámok kedvező változása mellett a lakosság szubjektív biztonságérzete is jelentősen javult. A pozitív változások eredményeképpen a marseille-i önkormányzati rendőrség a lakosság körében népszerűnek tekinthető, habár ennek komoly ára van az önkormányzati költségvetésre nézve, ugyanis az ottani rendőrség Marseille költségvetésének 11\%-ából gazdálkodik.

Összességében elmondható, hogy az államközpontú vegyes modell az önkormányzatok számára viszonylag nagy szabadságot és eszközök széles tárházát nyújtja egy-egy település közbiztonságának megteremtésében, illetve a közbiztonság megteremtéséhez való hozzájárulásban. Tény, hogy az államközpontú vegyes modellben a fő szerepet az állami rendészet látja, azonban ezen modellben az önkormányzatok érdemben képesek tehermentesíteni az állami rendészetet, illetve megvalósítani az önkormányzatok közbiztonsággal kapcsolatos vízióit, politikáját, hiszen ehhez a kellő jogszabályi támaszt megkapják.

36 Code de la santé publique 1312-1. cikkely.

37 Décret n 95-409 du 18 avril 1995 pris en application de lrarticle 21 de la loi du 31 décembre 1992 relative à la lutte contre 2. cikkely.

38 Code des transports 2241-1. cikkely.

39 Marseille önkormányzati rendészetét Marseille Önkormányzati Rendőrségének igazgatója, Marc Labouz mutatta be workshop keretében. A workshop létrejöttéhez nyújtott segítséget ezúton köszönöm a Fôvárosi Önkormányzati Rendészeti Igazgatóság vezetőségének. 


\section{Vegyes modell}

A vegyes modellhez tartozó államok rendőrségi rendszere, hasonlóan az államközpontú vegyes modellt alkalmazó államokhoz, a Tupman-modell szerint a decentralizáltnak tekinthető, ugyanis a települési önkormányzatok létrehozhatnak az állami rendőrség mellett önkormányzati rendőrséget is. A vegyes modell és az államközpontú vegyes modell közötti különbség az önkormányzati rendőrség hatáskörének terjedelmében rejlik, ugyanis a vegyes modellt alkalmazó államokban az önkormányzati rendőrség nem csupán kiegészítheti, hanem helyettesítheti az állami rendőrséget a településeken. A vegyes modellhez tartozó államokban, azon önkormányzatok területén, ahol létrehoztak önkormányzati rendőrséget vagy az állami rendőrséggel teljesen párhuzamosan kerül sor a feladatellátásra, vagy egyáltalán nem múködik állami rendőrség.

A vegyes modellt alkalmazó államok például Kanada, ahol egy önkormányzat közigazgatási területén az önkormányzati rendőrség mellett nem múködhet állami rendőrség, valamint Ausztria, ahol a szövetségi (állami) rendőrség (Bundespolizei) és az önkormányzati rendőrség (Gemeindewachkörper) egymás mellett élése valósul meg. A következő részben ez utóbbi önkormányzati rendészet alapjait mutatom be.

Ausztria önkormányzati rendészetére, eltérően a tanulmányomban bemutatott Szlovéniáétól és Franciaországétól, a folyamatos, máig tartó hanyatlás a jellemző. Kihagyva Ausztria rendészetének történetét, kiemelném, hogy egészen a második világháborúig az önkormányzati rendőrségek aktív és jelentős szereplői voltak a települési rendvédelmek, azonban az önkormányzati rendőrségek száma drasztikusan csökkenni kezdett a második világháborút követően, 1992-re például csak 45 múködő önkormányzati rendőrség maradt. Egy 1991-es alkotmányreform eredményeképpen az önkormányzati rendőrségek működésének jogalapja megszűnt Ausztriában, így egészen 1999-ig a megmaradt önkormányzati rendőrségek az illegalitás határán mozogtak. A helyzetet az 1999-es újabb alkotmányos reform oldotta fel, amikor is hivatalosan is hét évre visszamenő hatállyal elismerték az önkormányzati rendőrségek működését. ${ }^{40} \mathrm{Az}$ önkormányzati rendőrségek száma 1992 óta tovább csökkent, számuk jelenleg 37, ${ }^{41}$ amely szám hozzávetőlegesen 1,5\%-a az összes, 2357 osztrák helyi önkormányzatnak.

A 37 helyi önkormányzat valamivel több mint 300 önkormányzati rendőrségi dolgozót alkalmaz, amely szám szintén elenyésző a majdnem 30 ezer fővel rendelkező szövetségi rendőrségi állományhoz képest. ${ }^{42}$ Álláspontom szerint komoly szerepet játszik az önkormányzati rendőrségek csekély számában az a tényező, hogy történelmi okokból a tartományi székhelyek és más olyan települések számára, ahol bűnüldöző hatóságok múködnek, tiltott az önkormányzati rendőrség létrehozása. Önkormányzati rendőrség létrehozása és fenntartása rendkívül nagy költséggel jár az önkormányzatok számára és az osztrák szabályozás alapján a legnagyobb teherbíróképeséggel és

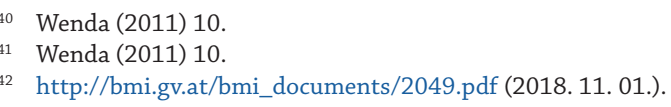


népességgel rendelkező települések számára nem lehetséges az önkormányzati rendőrségek kialakítása. ${ }^{43}$

A vegyes modellnek megfelelően az önkormányzati rendőrségek mellérendeltségi viszonyban vannak a szövetségi rendőrséggel, a két rendőrség hatásköre túlnyomórészt megegyezik egymással, azzal a kitétellel, hogy az önkormányzati rendőrségek feladatait az adott önkormányzati rendőrség mérete határozza meg. Minél nagyobb egy önkormányzati rendőrség, annál több feladatot láthat el. Azt, hogy egy önkormányzati rendőrség milyen feladatokat láthat el, a tartományi kormányzat határozza meg rendeletben. ${ }^{44}$

A két rendőrség közötti feladatmegosztásra jellemző a párhuzamosság, azaz a bűncselekményt vagy szabálysértést észlelő rendőrség jogosult az eljárásra. Ez koordinációs problémákat okozhat, ugyanis a jelenlegi szabályozási környezetben a rendőrségek egymás eljárásairól nem tudnak, kizárólag a jogerőre emelkedett szabálysértési vagy büntetőügyek tekintetében létezik olyan nyilvántartás, amelybe mindkét rendőrség betekinthet.

Az önkormányzati rendőrség rendőreinek jogállása és a szövetségi rendőrség rendőreinek jogállása, rangja, bérezése megegyezik egymással, a képzésre, továbbképzésre vonatkozó szabályok szintén azonosak.

Ausztria önkormányzati rendőrségei közül kiemelendő Baden bei Wien mint Ausztria legnagyobb önkormányzati rendőrségét működtető település. A badeni önkormányzati rendőrség mint a legnagyobb osztrák önkormányzati rendőrség 35 főállású és 6 részállású dolgozóval rendelkezik, akik kizárólag Baden közigazgatási területén, a szövetségi rendőrökkel párhuzamosan tevékenykedve látják el a feladataikat. Összehasonlításképpen feltétlenül említésre érdemes, hogy a badeni önkormányzati rendőrség mellett működő szövetségi rendőrség összlétszáma 45 fő, amelynek munkáját könnyíti, terheit részben átveszi az önkormányzati rendőrség. Baden bei Wien önkormányzati rendőrsége amellett, hogy átveszi és könnyíti a szövetségi rendőrség munkáját, közbiztonsághoz kapcsolódó szolgáltatások széles körét (például önvédelmi tanfolyamok, közbiztonsággal kapcsolatos előadások szervezése) biztosítja a lakosok számára, ezzel növelve elfogadottságát a településen, illetve hozzájárulva a „legbiztonságosabb osztrák város" 45 imázsának megteremtéséhez. Az önkormányzati rendőrség fenntartása Baden bei Wien költségvetésének 4\%-át emészti fel, és a fenntartáshoz sem a szövetségi állam, sem a tartomány nem járul hozzá.

Az ismertetett osztrák példa alapján levonható a következtetés, hogy mivel a vegyes modellben szinte teljes értékű rendőrséget hozhat létre egy önkormányzat, így az önkormányzati rendőrség hatékony partnere, esetenként helyettesíthetője lehet az állami rendőrségnek. A modellt alkalmazó államok önkormányzatai számára szinte minden eszköz rendelkezésre áll ahhoz, hogy egy település közbiztonságára vonatkozó politikájukat megvalósítsák, az ezzel kapcsolatos sikereket saját sikerükként kommunikálják.

43 Bundes-Verfassungsgesetz 78d.

44 Sicherheitspolizeigesetz Nr. 566/1991 9. § (3)-(4) bekezdés.

45 www.baden.at/de/unsere-stadt/sicherheit/ (2018. 11. 01.). 
A vegyes modell alapján létrejövő önkormányzati rendőrség fenntartása azonban komoly költségvetési forrásokat igényel az önkormányzatoktól, így az önkormányzati rendőrség sikere gyakorlatilag az önkormányzati rendőrség fennmaradásának záloga.

\section{Konklúziók}

Áttekintve az önkormányzati rendészeti modelleket, megállapítható, hogy bármelyik hatékony lehet a közbiztonság megteremtésében, nem mondhatjuk, hogy valamelyik jobb lenne, mint a másik. Az egyes modellek közötti különbség az önkormányzatok számára a közbiztonság megteremtéséhez biztosított eszközök számában van. Minél kevesebb eszközt biztosít egy állam az önkormányzatai számára a közbiztonság megteremtéséhez, annál jobban rá van szorulva az állami rendőrség közreműködésére.

Figyelembe véve, hogy az egyes államok, jórészt történelmi fejlődésük eredményeképpen, különböző eszközöket és eltérő hatásköröket biztosítanak az önkormányzatok számára a települési közbiztonsággal kapcsolatosan, kijelenthető, hogy az önkormányzatokon múlik, hogy milyen mértékben élnek ezen eszközökkel, gyakorolják-e a rendelkezésükre álló hatásköröket, ugyanis az önkormányzati rendészet néhány atipikus példa kivételével, ${ }^{46}$ állami támogatás hiányában, jelentős saját bevételek terhére finanszírozandó önkormányzati forrást igényel. A közbiztonság mint közszolgáltatás verseng más az önkormányzatok által nyújtott közszolgáltatásokkal, így az önkormányzati döntéshozóknak mérlegelniük kell, hogy megéri-e nekik a települési közbiztonságra pénzt áldozni, azaz a települési közbiztonság támogatása okoz-e változást lakosság életkörülményeiben. Amennyiben a politikai akarat rendelkezésre áll és az önkormányzat költségvetési forrásai ezt megengedik, akkor a szigorúan államközpontú modellt kivéve, az önkormányzat hatékony és esetenként komoly szereplő lehet a közbiztonság megteremtésében.

\section{IRODALOMJEGYZÉK}

Bacsárdi József (2017): A hazai és a szlovák önkormányzati rendészet összehasonlító elemzése. In Gaál Gyula - Hautzinger Zoltán szerk.: Pécsi Határôr Tudományos Közlemények XIX: Szent Lászlótól a modernkori magyar rendészettudományig. Pécs, Magyar Hadtudományi Társaság Határőr Szakosztály Pécsi Szakcsoportja.

Bacsárdi József (2018): A francia önkormányzati rendészet összehasonlító elemzése. In Koltay András szerk.: Iustum Aequum Salutare XIV. 2018/2. Budapest, Pázmány Péter Katolikus Egyetem Államés Jogtudományi Kar.

Bacsárdi József - Christián László (2017): Hol tart jelenleg az önkormányzati rendészet? In Christián László szerk.: Rendészettudományi kutatások: Az NKE Rendészetelméleti Kutatómühely tanulmánykötete. Budapest, Dialóg Campus Kiadó.

46 Ilyen atipikus példa hazánkban a mezei őrszolgálatok állami támogatása. Lásd: a mezei őrszolgálat megalakításához, fenntartásához és működéséhez nyújtandó állami hozzájárulás igénybevételének rendjéről és feltételeiről szóló 64/2009. (V. 22.) FVM-PM együttes rendelet. 
Bacsárdi József - Christián László (2017): Katalán rendészeti igazgatás, a helyi rendészet Barcelonában. Belügyi Szemle, 65. évf. 10. sz. 26-41.

Christián László (2011): A rendészet alapvonalai, önkormányzati rendőrség. Győr, UNIVERSITAS-GYÖR Nonprofit Kft.

Christián László (2016): Rendőrség és rendészet. In Jakab András - Gajduschek György szerk.: A magyar jogrendszer állapota. Budapest, MTA Társadalomtudományi Kutatóközpont.

Donelly, Daniel (2013): Municipal Policing in the European Union Comperative Perspectives. Hampshire, Palgrave Macmillan.

Mawby, Rob (2006): Policing Across the World. Issues for the Twenty-first Century. New York, Routledge. Sotlar, Andrej - Dvojmoč, Miha (2015): Municipal Warden Services in the Pluralised Policing Environment. Journal of Criminal Investigation and Criminology, Vol. 66, Issue 4. 330-341.

Tupman, Bill - Tupman, Alison (1998): Policing in Europe: Uniform in Diversity. Exeter, Intellect.

\section{Internetes források}

www.baden.at/de/unsere-stadt/sicherheit/ (2018. 11. 01.)

http://bmi.gv.at/bmi_documents/2049.pdf (2018.11. 01.)

www.bmi.gv.at/magazinfiles/2011/11_12/files/gemeindewachen.pdf (2018. 11. 01.)

https://goo.gl/gcpfmq (2018. 11. 01.)

https://goo.gl/RDQPXi (2018. 11. 01.)

\section{Jogforrások}

1996. évi LIII. törvény a természet védelméről.

1997. évi CLIX. törvény a fegyveres biztonsági őrségről, a természetvédelmi és a mezei őrszolgálatról. 1999. évi LXIII. törvény a közterület-felügyeletről.

2009. évi XXXVII. törvény az erdőről, az erdő védelméről és az erdőgazdálkodásról.

2013. évi CII. törvény a halgazdálkodásról és a hal védelméről.

Code général des collectivités territoriales.

Code de la sécurité intérieure.

Code forestier.

Code des transports.

Code de l'environnement.

Code de la santé publique.

Décret n 95-409.

Bundes-Verfassungsgesetz.

Sicherheitspolizeigesetz Nr. 566/1991.

Code des assurances.

\section{ABSTRACT}

\section{Local Governmental Law Enforcement Models}

BACSÁRDI József

By comparative analysis of some local governmental law enforcement systems, five major local governmental law enforcement models can be distinguished. The various local governmental law enforcement models are described with a schematic presentation of the local governmental law 
enforcement system of a selected foreign state (Finland, Slovenia, France, Austria), focusing on the main features of each model in relation to the Hungarian local governmental law enforcement regulations.

Keywords: local governmental law enforcement, municipal police, local government 